\title{
Aspekte van Stoker se kritiek op die Wysbegeerte van die Wetsidee
}

\author{
L.F. Schulze \\ Departement Dogmatologie en Ekklesiologie \\ Potchefstroomse Universiteit vir $\mathrm{CHO}$ \\ POTCHEFSTROOM
}

\begin{abstract}
Some points of Stoker's criticism of the Philosophy of the Creational Idea

Stoker had appreciation for many aspects of the Calvinist philosophy of Vollenhoven and Dooyeweerd, as is evident inter alia from his arlicles in Die Wagtoring (1932-1933) and in Koers (1937-1941). Yel, he also had some misgivings about the new philosophy. Some of his resenvations. illustrating his independence as philosopher, are treated in this article, viz. (1) his criticism of the 'law-idea': (2) his rejection of the notion that theology is a special science (vakwetenskap), and (3) his remarks that some humanistic and idealistic elements are incorporated in the Calvinist philosophy of Vollenhoven and Dooyeweerd. To undercut these deficiencies in the philosophy of Vollenhoven and Dooyew'eerd he proposed his Philosophy of the Creational Idea.
\end{abstract}

\section{Inleiding}

Hierdie artikel belig 'n bepaalde faset van Stoker en vertel gevolglik nie die hele verhaal nie. 'n Mens sou ook kon skryf oor "Stoker en die Wysbegeerte van die Wetsidee", maar dit sal veel meer as 'n artikel beslaan; of oor "Stoker se waardering vir die Wysbegeerte van die Wetsidee", want dit was beslis by hom aanwesig (vgl. Stoker, 1932(1):20-21; 1933(6):14-15; 1937b:2-7; 1938a:14). Dit is bekend dat hy baie insigte van die Wysbegeerte van die Wetsidee oorgeneem het; tog het hy geen ongekwalifiseerde aanhanger van die Wysbegeerte van die Wetsidee geword nie maar sy selfstandigheid as filosoof behou. Hy het nie alleen

1 Om binne dic bestck van 'n artikel te bly, is hicrdic oorsig bloot kursorics. Bowendien is dit selckticf in dic sin dat hoofsaaklik op Stoker se bydraus in Koers en sy voorloper. Die Wagloring. gekonsentrecr word. Sodoende kan dic huidige lesers van Koers 'n indruk kry van Stoker se bydraes in hicrdic tydskrif. Vir 'n vollediger oorsig van sy bydracs in Koers, kyk Stokcr (1970:437-438). 
baie insigte van Vollenhoven en Dooyeweerd oorgeneem nie, maar het die insigte in sy eie Wysbegeerte van die Skeppingsidee verwerk, verfyn en uitgebou. So byvoorbeeld het hy Vollenhoven se onderskeidings van die visie op die verhouding van God en kosmos in sy artikel "God (theos) en Wêreld (kosmos)" verder uitgebou en die onderskeidings verfyn (Stoker, 1937a:4-13; 1970:9-17). Reeds in sy eerste artikel oor die Wysbegeerte van die Wetsidee (Stoker, 1932(5):14-28) het hy egter ook kritiek op die beskouings van Vollenhoven en Dooyeweerd gehad. Later (1937b:7) het hy sy besware bly handhaaf ná die verskyning van Vollenhoven se Het Calvinisme en de reformatie van de wysbegeerte (1933) en De Wysbegeerte der Wetsidee van Dooyeweerd (1935) en die volgende opmerking gemaak:

Nie orals sal prof. Dooyeweerd se beskouinge aangeneem word nie, en selfs al sou hierdie wysbegeerte in sy geheel omgewerk moet word, dan nog sal die grootste gedeeltes daarvan weer gebruik moet word in die omgeboude stelsel, omdat hulle van blywende waarde is.

Juis die selfstandigheid van Stoker as denker word in hierdie artikel belig. Dit word nie gedoen deur aandag te gee aan die wyse waarop Stoker insigte van die Wysbegeerte van die Wetsidee oorgeneem en selfstandig verwerk het nie, maar deur slegs aandag te gee aan sy kritiese opmerkings oor die Wysbegeerte van die Wetsidee, en hoe hy ten slotte in sy eie filosofie die gebreke wou oorkom.

Reeds in Februarie 1932 het die geniale jong filosoof, 32 jaar oud (hy het in April 33 geword), sy waardering én kritiek op die Wysbegeerte der Wetsidee, wat in wording was, bekend gemaak in Die Wagtoring.

Gedurende 1937 tot 1941 het Stoker dit in Koers opgevolg met 'n reeks artikels oor die Wysbegeerte van die Wetsidee en het hy ook oor 'n Calvinistiese wysbegeerte geskryf (vir die motivering van laasgenoemde reeks, kyk Stoker, 1940a:1, verw. 1), waarin hy weereens benewens waardering ook kritiek op bepaalde aspekte van die Wysbegeerte van die Wetsidee uitgespreek het. Die volgende aspekte van Stoker se opmerkings word hier behandel:

* Sy kritiek teen die begrip wetsidee.

* Sy kritiek op die siening dat teologie 'n vakwetenskap is.

* Sy kritiek op sekere idealistiese en humanistiese elemente in die Wysbegeerte van die Wetsidee. 


\section{Die wetsidee}

\subsection{Stoker oor die 'wetsidee'}

Stoker se kritiek op die wetsidee belıels verskeie fasette, waarvan die belangrikste die volgende is: die wetsidee is eerstens te eng om die geheel in die verskeidenheid van die skepping na reg te verstaan; die wetsidee is tweedens as sodanig te algemeen en kan nie die besondere karakter van 'n Calvinistiese wysbegeerte uitdruk nie.

Bogenoemde kritiekpunte van Stoker word vervolgens baie kursories aangedui.

\subsubsection{Die term wetsidee is te eng}

Stoker (1932(5): 13-28) bespreek uitvoerig sy besware teen die wetsidee as Archimedespunt vir 'n Calvinistiese wysbegeerte na aanleiding van die begrippe sislase, sin en kosmiese tyd soos dit in die Wysbegeerte van die Wetsidee figureer.

Vollenhoven en Dooyeweerd voer die begrip sistase van wetskringe in oin substansie, wat volgens hulle die produk van die heidense denke is, te vervang. Sistase is dan aanduiding van die imnige samehang van bepaalde wetskringe soos dit in 'n 'ding' of in ' $n$ 'dit' of ' $n$ 'dat' gegee is (kyk Stoker, 1932(4):25). Anders geformuleer: "So ' $n$ 'dit' of ' $n$ 'dat', wat 'deel het' aan ten minste twee wetskringe, en 'n subjekseenheid uitmaak, word genoem 'n sistase, as jy rekenskap wil gee van die meer-sydige verhand waarin dit staan" (1932(4):26).

Stoker (1932(5):14) het nie beswaar teen die begrip sistase nie, maar meen dat die sistases nader gekwalifiseer moet word deur suhstansialiteit en nie-substansialiteit. As voorbeelde van die voorgaande onderskeiding tussen sistases noem Stoker die volgende: 'n driehoek versus 'n mens of 'n plant, 'n eliptiese (en logies energielose) beweging versus in klip of 'n dier; ' $n$ denke of ' $n$ wilsbeslissing versus ' $n$ mens of ' $n$ dier. Ons kan al die voorbeelde wel sistases noem, maar Stoker meen dat die voorbeelde wat links van die "versus" staan, geen substansies is nie, maar dié wat regs daarvan staan, wel substansies is.

Stoker pleit dus vir 'n Calvinistiese substansiebegrip wat van sy immanentfilosofiese en gevolglik heidense konnotasie gesuiwer is ten einde die noodsaaklike - in die naïewe ervaring gegewe - verskil tussen sistases te erken. Sistase is aanvaarbaar maar as begrip onvoldoende om die verskeidenheid in die skepping te teken en Stoker (1932(5):15) herlei hierdie mankement na die inherente gebrekkigheid van die wetsidee as Archimedespunt:

Solang die argimedes-punt van 'n Kalvinistiese wysbegeerte net die Wetsidee is, sal daar probleme en probleem-reste wees wat dit nie bevredigend 
kan oplos nie, en wat alleen bevredigend opgelos sal kan word in 'n nog ruimere beskouingswyse gegee met die skeppingsbeginsel as argimedespunt.

Om Stoker se gedagtegang te volg is van sy kritiese opmerkings oor sistase hierbo in besonderhede toegelig. Verder kan net genoem word dat Stoker die "engheid" van die Wetsidee ook aantoon na aanleiding van Dooyeweerd se stelling dat die hele werklikheid sin is en deur laasgenoemde se poging om die eenheid van die sistase meer begryplik te mak met behulp van kosmiese tyd (kyk 1932 (5):21-28). Stoker stel dat die werklikheid sin het maar terselfdertyd ook méér as net $\sin$ is. Ten slotte vat Stoker $(1932(5): 28)$ sy kritiek in 'n enkele sin saam: Sin plus tyd is nie werklikheid, skepping nie.

In die prolegomena van De Wijsbegeerte der Wetsidee beantwoord Dooyeweerd $(1935,1: 57-64,71)$ aspekte van bogenoemde kritiek van Stoker. Dooyeweerd bespreek uitvoerig die redes waarom hy aan wetsidee bly voorkeur gee (Dooyeweerd, 1935,1:59-61). 'n Calvinistiese filosofie moet van die wetsidee uitgaan omdat wysgerige stelsels hulle in die algemeen altyd aan ' $n$ bepaalde wetsidee oriënteer $(1935,1: 57-68)$.

Op laasgenoemde aspek reageer Stoker op sy beurt deur aan te toon dat die begrip wetsidee te algemeen is en 'n nadere kwalifikasie vereis om sy spesifiek Calvinistiese karakter aan te toon.

\subsubsection{Die term wetsidee is te vaag}

Stoker (1937d:20) stel eers Dooyeweerd se argumente ten gunste van die wetsidee:

Die wetsidee is die grondidee van die wysbegeerte. Reeds antieke en Middeleeuse, maar ook moderne wysgerige stelsels van naam, het die wysgerige denke uitdruklik vasgebind aan die idee van 'n Goddelike wêreldorde, gekwalifiseer as lex aeterna, harmonia praestabilita, ens. Die geloof aan 'n wêreldorde is die eerste veronderstelling, die religieuse verankering van die wysgerige denke, en is gerig op die sintotaliteit van die kosmos. Dit is nie moeilik om aan te toon dat elke wysgerige stelsel in een of ander wetsidee gegrond is nie. Die Calvinistiese wetsidee het egter die voordeel bo ander tipes wetsideë, dat die wet hier nie verabsoluteer word nie, maar as grens tussen Skepper en skepping erken word ... (vgl. Dooyeweerd, 1935, 1:5761).

Stoker (1937d:22) kritiseer Dooyeweerd se opvatting soos volg:

Elke wetenskap soek wette. Die wysbegeerte self soek die orde van die hele kosmos, die universele samehang van alle wette. As alle wysbegeerte hierin ooreenstem, dan is juis die besondere karakter van ons Calvinistiese wysbegeerte nie gewaarborg in die term wysbegeerte van die wetsidee nie; 
bowendien sou hierdie term dan toutologies wees, nl. omskryf: die wetsidee-wetenskap van die wetsidee. Met ander woorde in die term 'wysbegeerte' lê reeds opgesluit, dat dit die orde van die kosmos ondersoek. Om nou verder ons 'wysbegeerte van die wetsidee' te onderskei van die 'wysbegeertes van die wetsidee' vanuit ander standpunte beskou, moet Prof. Dooyeweerd tenminste 'n nader bepaling in die naam invoeg, of daaraan toevoeg, soos 'wysbegeerte van die wetsidee, vanuit transendensiestandpunt benader'. Omdat hy volgens sy eerste argument ' $n$ bepaling kies, wat aan elke wysbegeerte eie is, het elke wysbegeerte reg op die naam 'wysbegeerte van die wetsidee' en mag hy die naam nie meer opeis as aanduiding van sy eie wysgerige stelsel alleen nie.

Daarteenoor bly Stoker praat van 'n wysbegeerte van die skeppingsidee omdat dit Skepper teenoor skepping nog duideliker afgrens en "die wesenlike Christendom meer onmiddellik" pak en "meer in ons midde" leef (Stoker, 1937d:24).

'n Mens begryp Stoker se intensie. Genesis begin immers nie met die feit dat God sy wet gegee het nie maar dat Hy hemel en aarde geskep het. Wet veronderstel reeds ' $n$ Wetgewer en die skepping waarvoor dit geld.

Die merkwaardige is dat Dooyeweerd sy grondliggende konsepsie (wetsidee) nie primêr uit die Skrif put nie maar die religieuse verankering van die wysgerige denke put uit die struktuur van antieke en moderne wysgerige stelsels, naamlik die geloof aan 'n wêreldorde. Die Skrif begin immers met skepping (Gen. 1:1; Jes. 40:12-14) en teken die Skepper as die een wat orde (wet) in sy skepping handhaaf (Jes. 40:26). Daarenteen sê Dooyeweerd uitdruklik (1935,1:57):

Deze term (wetsidee - L.F.S.) werd door mij gevormd (my kursivering), toen ik bijzonder getroffen was door het feit dat zoowel de groote stelsels der antieke als der middeleeuwsche wijsbegeerte en niet minder enkele groote stelsels der moderne philosophie (als dat van Leibniz) uitdrukkelijk het wijsgerig denken orienteerden aan de idee ener goddelijke wereldorde, die als lex aeterna, harmonia preastabilita, enz. werd gekwalifiseerd.

In deze idee van de wet, waarin de idee der subjectiviteit was begrepen, was inderdaad apriorisch positie gekozen ten aanzien van de centrale voorvragen van het wijsgeerig denken (my kursivering).

Eers later kom die Christelike dimensie (aposteriories) daarby (Dooyeweerd, 1935,1:58):

Daarbij kwam, dat het Calvinisme ... in Schrifturlijke lijn van meet af allen nadruk heeft gelegd op de wet als de onoverkomelijke grens tusschen Schepper en schepping ... 
Samevattend: Dooyeweerd kom van die wet na die subjek (God as Wetgewer het geskep); Stoker wil vanuit die skepping by die wet kom (God as Skepper het sy wet gegee).

Die geloof aan 'n wêreldorde mag eie aan alle wysgerige stelsels wees, maar dit is nie eie aan die Christendom met sy geloof in die Drie-enige God nie.

\section{Teologie as vakwetenskap}

\subsection{Stoker se kritiek}

\subsubsection{Wysbegeerte en teologie}

In die eerste artikel in Die Wagtoring (1932(1):20-26), wat handel oor die nuwere wysbegeerte aan die Vrije Universiteit, bespreek Stoker die belang van die nuwe wysbegeerte. Hy meen dat die betekenis van 'n eie Calvinistiese wysbegeerte veral daarin lê dat dit eerstens die "nie-kalvinistiese wysbegeerte beter te lyf" kan gaan (1932(1):21), tweedens 'n staanplek (Archimedespunt) buite die kosmos bied, vanwaar die hele kosmos in sy eenheid en verskeidenheid oorsien kan word, en derdens ' $n$ gesonde arsenaal bied waaruit die dogmatiek kan put. In laasgenoemde verband - vóór die Archimedespunt verder bespreek word - kom dan as "'n tweede inleiding" eers "Wysbegeerte en Teologie" ter sprake (1932(1): 23 e.v.).

Uit die betoog is twee sake duidelik: (a) dat Stoker nie teologie as vakwetenskap sien nie - iets waaraan hy konsekwent vasgehou het; (b) dat hy in hierdie artikel nie die onderskeid tussen wysbegeerte en teologie wil bespreek nie, maar veral die betekenis van 'n Calvinistiese filosofie vir die teologie wil belig. Die artikel as geheel wil immers die groot betekenis van 'n Calvinistiese wysbegeerte, soos dit deur Vollenhoven en Dooyeweerd ontwikkel word, belig.

Stoker toon dan aan dat die teologie, en met name die dogmatiek, die hulp van die filosofie nodig het. Stoker (1932(1):23-24) stel dit kategories:

Die Teologie moet sig van die wysbegeerte bedien ... Die dogmatiek sou sonder die wysgerige hulp-metodes nie te ver vorder nie. Of anders gestel: die dogmatiek handel nie net oor God drieënig en die saligmaking van die mens nie, maar ook oor kwessies van beginsels, van metodes, van die wese van wetenskap, oor die wêreld in sy oorspronklike staat, oor die sonde, oor die oorerwing van sonde, oor gees, siel en liggaam, ensovoorts meer - sake dus, wat ook in die terrein van die wysbegeerte val, en eintlik in die wysbegeerte tuis hoort. Die dogmatiek sien hierdie verskynsels wel volgens die lig van Gods openbaring, - die hoofbron van kennis, - en kan die 
openbaring van God nie geïsoleer van Sy skepping behandel nie, maar moet sig dan tog ook op ' $n$ terrein begewe, wat die wysbegeerte eie is.

Omdat die gereformeerde dogmatiek voortdurend krities standpunt moet inneem teenoor ander dogmatieke, wat vrylik van heidens-wysgerige beskouinge gebruik maak, kom die gereformeerde dogmatiek "in volle kontak met die heidense wysbegeerte" (1932(1):23). Daarom is dit onmoontlik om wysbegeerte en teologie in die dogmatiek te skei en teologie heeltemal geïsoleerd van wysbegeerte te probeer beoefen.

Die kontak tussen teologie en wysbegeerte is selfs nog inniger as wat hierbo aangetoon is. Dié nouer kontak word daarin sigbaar dat die begrippe waarmee teoloë werk, dikwels uit die filosofie geput of volgens wysgerige aanwysing gekonstrueer word. Hierdie feitlik outomatiese vorming van begrippe is gemeengoed van ' $n$ bepaalde kultuur in 'n bepaalde eeu en word kritiekloos en vanself in die teologie oorgeneem. Stoker $(1932(1): 24)$ verduidelik hierdie oorname van begrippe soos volg:

Neem bv. die opvatting van materie, ruimte, tyd, ens. of van substansie, en attribuut, of van lewe, gees, siel, liggaam, ens., ens. in een of ander eeu, en bestudeer in hoeverte die teoloë van so 'n eeu die begrippe in die gebruiklike betekenis handhaaf, dan sal $u$ verbaas wees om te sien hoeveel heidense elemente selfs in die Kalvinistiese teologie ongemerk insluip. Dis verstaanbaar. Die heidense elemente in sulke begrippe soos lewe, bewussyn, gees, ens. is vermasker teenwoordig en lyk dikwels op die eerste blik pragtig versoenbaar, met wat die Skrif hieromtrent sê. Hulle word sonder argwaan aanvaar, omdat daar geen beter of ander begrippe is nie, wat van die heidense elemente bevry is nie.

Stoker illustreer bogenoemde aanhaling met 'n verwysing na dit wat Kuyper en Bavinck oor siel en gees skryf. Wat hulle oor die begrippe skryf, is seker in ooreenstemming met die Skrif "sover as hulle kan sien, maar in die detaillebepaling van hierdie begrippe sluit hulle hul aan by die algemeen-heersende detaillebepaling, wat hulle van af hulle skool-dae tot hul dood-toe verneem het". Wanneer ons die invloed van Plato en Aristoteles dwarsdeur die Middeleeue tot vandag toe in aanmerking neem, "hoef ons ons niks te verwonder as ons sou ontdek dat selfs Kuyper en Bavinck in baie opsigte meer platonies en aristoteliaans as skriftuurlik dink" nie (Stoker, 1932(1):25).

Teen bogemelde agtergrond, soos deur Stoker geskets, word die geweldige belang van die "nuwere Wysbegeerte aan die VU" ooglopend. Hierdie Calvinistiese filosofie is belangrik vir 'n Calvinistiese lewensbeskouing en vergemaklik dit vir 'n mens om op te merk wanneer iemand (miskien ongemerk) heidens dink. Met 'n gesonde Calvinistiese filosofie as bondgenoot sal die gereformeerde teologie ook veel meer kan uitrig as daarsonder, "veral in die bestryding en 
weerlegging van die moderne teologieë deur hulle op hulle eie terrein te ontmoet en te ontsenu" (Stoker, 1932(1):26).

Stoker is bewus daarvan dat die beroep op die Skrif die finale maatstaf vir die Calvinistiese teologie is. Dit is dan ook duidelik uit sy betoog dat die Calvinistiese wysbegeerte nie te hulp geroep word as ekstra gesagsbron om die Skrifberoep meer krag te verleen nie. Maar wat doen die gereformeerde teoloog as sy teenstander die Skrif nie as onfeilbaar beskou nie? Dán help die Skrifberoep hom immers nie om die saak met sy teenstander te besleg nie! Dit is hiér waar die Calvinistiese wysgerige beskouinge as 'n verdere "hulpmetode van bestryding" te pas kom om "die wysgerige onhandhaafbaarheid van die beskouinge van die teëstanders" aan te toon (Stoker, 1932(1):26).

\subsubsection{Watter wetenskap het prioriteit?}

In die lig van die wisselwerking tussen wysbegeerte en teologie soos Stoker dit in sy eerste artikel in Die Wagtoring uiteengesit het, sou 'n mens kon vra watter wetenskap ten slotte prioriteit het: wysbegeerte of teologie? Moet die wysbegeerte aan die teologie voorskryf of andersom? Hierdie vrae was akuut aan die Vrije Universiteit.

In 'n besonder insiggewende artikel lig Stoker (1940b) effens die sluier oor die binnegevegte aan die Vrije Universiteit in die dertigerjare tussen Hepp (en sy leerlinge, D. Prins, B.J. de Klerk en F.J.M. Potgieter) aan die een kant en Vollenhoven en Dooyeweerd aan die ander kant. In hierdie stryd tusssen teoloë en filosowe kies Stoker (1940b:9) nie kant nie, maar toon heel nugter die tekortkominge van albei groepe se standpunte aan:

Vir Prof. Dooyeweerd is die wysbegeerte die grondwetenskap van die teologie. Vir Prof. Hepp is die teologie die grondwetenskap van die wysbegeerte. Op die wyse wat elk sy standpunt uitwerk is dit my egter duidelik, dat volgens die metode van Prof. Dooyeweerd die teologie nie tot sy reg kan kom nie, en dat volgens die metode van Prof. Hepp die wysbegeerte nie tot sy reg kan kom nie.

In die lig van bogenoemde stel Stoker (1940b:9) dan sy opvatting van wat teologie is:

Teologie is geen vakwetenskap nie soos Prof. Dooyeweerd wil nie, maar koningin van alle ander wetenskappe; en die wysbegeerte vorm sy grondbegrippe met behulp van die teologie en nie omgekeerd nie.

Stoker voeg hieraan ' $n$ verwysing van meer as 'n bladsy lank toe (Stoker, 1940b: 9-10 - verw. 8) om sy standpunt te motiveer. Die kern daarvan is die volgende: 
... tog moet ons hier tweeërlei (sic) onderskei, nl. a, die godsdiens as 'n verskynsel in die kosmiese realiteit en b, die hier aan die mens geopenbaarde waarhede van 'n kosmies transendente God. Die eerste is 'n gegewe in die kosmiese realiteit, die laaste is transendente openbaring, d.w.s. openbaring van iets wat nie kosmiese realiteit is nie. Die ondersoek hiervan kan geen vakwetenskap wees nie, want die geopenbaarde waarhede Gods is as waarhede Gods nie 'n deel, 'n 'vak', van die kosmos nie. Daarom is teologie geen vakwetenskap nie, nieteenstaande dit as wetenskap van die mens kosmiese aktiwiteit en kosmiese besit is. Vakwetenskap is egter wel dit onder a, gegee, nl. godsdienswetenskap, waaronder val godsdienssielkunde, godsdiensgeskiedenis, godsdiensfenomenologie, godsdienssosiologie, ens. (vgl. ook Stoker, 1941:261-262).

\subsubsection{Terreinafbakening}

In 'n latere artikel het Stoker (1940c) die terreinafbakening van teologie, filosofie en die vakwetenskappe breedvoerig uiteengesit (kyk ook Stoker, 1941).

Die meningsverskil oor die taak en terrein van onderskeidelik wysbegeerte en teologie tusssen Hepp aan die een kant en Vollenhoven en Dooyeweerd aan die ander kant noop Stoker om sy eie standpunt hieroor uiteen te sit.

Hy begin deur ses redes vir die meningsverskil te bespreek (Stoker, 1940c:102104). In die redes verwys hy na die meningsverskille in Nederland sonder om name te noem en word sy eie standpunt reeds sigbaar. Ondat Stoker se eie standpunt reeds in die genoemde redes sigbaar word, kom enkeles hier ter sprake.

* Sommige handhaaf, sê hy, dat die bestaansreg van 'n Christelike wetenskap te vinde is in die gerigtheid van die wedergebore hart van die Christenwetenskaplike op God, in teenstelling met die ongelowige wetenskapsbeoefenaar, wie se hart afvallig op die tydelike dinge gerig is. Ander meen dat die bestaansreg van 'n Christelike wetenskap rus in die objek van wetenskaplike ondersoek, dit wil sê in die erkenning van die gegewenheid dat hierdie aardse werklikheid en waarheid van goddelike oorsprong is. Stoker meen dat albei opvattings eensydig is en dat die een sowel as die ander erken moet word as grondslag van 'n Christelike wetenskap. In sy kommentaar lewer hy reeds versigtige kritiek op die Wysbegeerte van die Wetsidee, asof dit in 'n Christelike wetenskap slegs om die (subjektiewe) gerigtheid daarvan gaan en nie ook om die (objektiewe) inhoud van die wetenskap nie. Stoker (1940c:102) stel dit soos volg:

M.i. het sowel die menslike subjek ... 'n religieuse apriori in sy uit die hart opkomende geloofshouding, as die wetenskapsobjek wat van en tot God is. Vir die waarheid van 'n Christelike wetenskap is dit egter nie normatief om jou te beroep op die Christelikheid van die be- 
oefenaar daarvan nie, want al is hy wedergebore, kan hy in hierdie sondige bedeling nog onware beskouinge oor velerlei sake ontwikkel. Alleen vir die werklikheid, vir die historiese gewordenheid van die Christelike wetenskap is dit ' $n$ sine qua non dat die beoefenaar daarvan 'n Christen sal wees. Vir die waarheid van ' $n$ Christelike wetenskap is normatief dat dit sal ooreenstem met die geopenbaarde waarheid en werklikheid. Vir die waarheid van 'n Christelike wetenskap is dus die ontologies religieuse apriori die waarborg ... Daarom sal ons in die onderskeid tussen teologie, wysbegeerte en vakwetenskap moet uitgaan van die geopenbaarde waarheid en werklikheid en nie van die mens nie, ook al sien ons sy denke en ander funksies uit die hart 'opkom'.

* Selfs waar Calviniste saamstem oor die kenbronne van wetenskap, naamlik Skrif en skepping, is daar nog verskil van mening oor hoe teologie, wysbegeerte en vakwetenskappe onderskei moet word. Die meningsverskil is daaraan te wyte dat "hulle te simplisties net met een principium divisionis wil uitkom" (Stoker, 1940c:103). As voorbeelde van die simplistiese verdelingsbeginsel word die volgende opvattings genoem: (i) teologie het net met die Skrif te doen, die ander wetenskappe net met die kosmos; (ii) teologie is beperk tot die ondersoek van die waarheid van God (sy Wese en eienskappe), terwyl die ander wetenskappe die kosmos ondersoek; (iii) die wysbegeerte ondersoek alles terwyl teologie tot 'n deel van die kosmos beperk word, naamlik tot dit wat in verband staan met die godsdienstige funksie; (iv) alles word saamgevat onder teologie, wat die beginsels vir alle ander wetenskappe moet voorskryf.

* Stoker (1940c:103) meen dat hier inderdaad moeilikhede bestaan "wat ' $n$ te simplistiese oplossing van ons probleem weerspreek".

Nadat die redes vir die meningsverskille onder Calviniste bespreek is, stel Stoker vervolgens positief sy eie standpunt. Teenoor die enkele (simplistiese) verdelingsbeginsel wat gebruik word om teologie, wysbegeerte en vakwetenskappe te onderskei, stel Stoker dat hier twee verdelingsbeginsels (principia divisionis) gebruik moet word om uit die moeilikheid te kom: eerstens die hoofonderskeiding van terreine (wat as't ware isoleer) en hierop gefundeer die hoofonderskeidinge van blikrigtinge (wat weer verband lê). Alleen op hierdie manier, meen Stoker (1940c:104) "kom onderskeiding en samehang tot hul reg". Hy sê:

Die geopenbaarde waarheid en werklikheid (in Skriftuur en Natuur geopenbaar) is nie EEN nie, maar TWEE, nl. Skepper en skepping, of God en kosmos. Ons kan beide skerp onderskei.

Wat die skepping of kosmos betref, kan weer onderskei word tussen die skepping as eenheid of totaliteit en die oeronderskeidinge in die kosmos. Die kosmiese 
eenheid én verskeidenheid is onherleibaar tot mekaar en sluit gevolglik alle pluralistiese sowel as monistiese kosmosbeskouings uit.

Die logiese onderskeidings tussen God en kosmos, en wat laasgenoemde betref, tussen die kosmos as eenheid en die kosmos as verskeidenheid, bied 'n voorlopige onderskeiding van die terreine van teologie, wysbegeerte en vakwetenskappe. Stoker (1940c:105) som dit só op:

Teologie is die wetenskap van die geopenbaarde waarhede Gods; filosofie is die wetenskap van die onselfgenoegsame, wetsonderworpe kosmiese totaliteit; die vakwetenskappe ondersoek elk 'n kringsoewereine onherleibare deel van die kosmiese, wetsgebonde verskeidenheid.

Naas bogenoemde "hoofonderskeiding van terreine", wat logies skerp deurvoerbaar is in die onderskeiding van die wetenskappe volgens hulle terreine, volg die tweede indelingsbeginsel van blikrigting, wat die samehang van God en kosmos enersyds, en van die kosmiese eenlheid en verskeidenheid andersyds in ag neem. Die drieërlei samehangsbeginsels, wat impliseer dat die wetenskappe wel onderskeibaar is maar nie van mekaar isoleerbaar is nie, gee ons drieërlei blikrigting, naamlik (i) na God; (ii) na die kosmiese totaliteit, en (iii) na ' $n$ besondere gegewe in die kosmos.

Stoker (1940c:105-106) som sy betoog soos volg op:

Ons het dus drie terreine: God, kosmiese totaliteit en kosmiese verskeidenheid, en hierop gefundeer drie blikrigtinge: direkte betrokkenheid van die kosmiese totaliteit en verskeidenheid op God, die betrokkenheid van 'n besondere kosmies-onherleibare verskynselgroep op die kosmiese totaliteit en die besonderheid van so ' $n$ verskynselgroep. Hierdie dubbele, terreinonderskeidende en samehangbiedende principia divisionis gee ons ' $n$ uiteindelike basis vir onderskeiding van teologie, filosofie en vakwetenskap.

Op grond van bogenoemde dubbele onderskeiding van terrein en blikrigting onderskei Stoker (1940c:106) dan die wetenskappe soos volg:

Teologie is a. die wetenskap van die geopenbaarde waarhede Gods (bv. sy wese en eienskappe) en b. van die kosmiese totaliteit en kosmiese verskeidenheid, insover hulle onmiddellik van God afhang, d.w.s. direk op God betrokke is ...

Filosofie is a. die wetenskap van die (deur God geskape) onselfgenoegsame, wetsgebonde kosmiese totaliteit, en $b$. van die plek wat die onderskeie, kosmies-onherleibare en wetsgebonde verskynselgroepe in hierdie kosmiese totaliteit inneem.

'n Vakwetenskap bestudeer 'n (deur God geskape) onselfgenoegsame en onherleibare (van ander onderskeibare, maar tog daarmee samehangende) 
wetsgebonde verskynselgroep in sy besonderheid en besondere wetmatigheid.

Stoker verfyn die onderskeidings tussen die wetenskappe en toon terselfdertyd hulle vervlegtheid aan as hy sê (1940c:106):

Die kosmiese totaliteit en verskeidenheid staan egter ook onder die wet en is in hul wetbepaaldheid, in hul wetsonderhorigheid ook middellik of indirek van God afhanklik. Met hierdie onselfgenoegsame, unieke wetsgebondenheid van die kosmiese totaliteit en kosmiese verskeidenheid het die teologie materialiter niks te doen nie. Dat God die kosmos in sy geheel en in sy verskeidenheid wetmatig georden het, stel die teologie vas, maar wat die universele en besondere kosmiese wette is, bestudeer die filosofie en die vakwetenskappe. Dat God byvoorbeeld plante en diere in soorte geskape het, stel die teologie uit sy Skrifeksegese vas, maar hoe die soorte onderskei moet word, elk volgens sy eie aard en wat hierdie eieaard en eiewetmatigheid is ondersoek die teologie nie, maar die biologie.

Ten slotte meen Stoker dat hierdie onderskeiding van teologie, wysbegeerte en vakwetenskappe konsekwent deurvoerbaar is, toon hy aan dat al drie saamhang en dat die wetenskapsgebou 'n eenheid is, en dat genoemde onderskeidings "die eenheid van die waarheid en die wetenskap" waarborg (Stoker, 1940c:107).

\section{Idealistiese en humanistiese trekke}

Stoker meld ook dat daar na sy mening humanistiese en idealistiese trekke (tendense) in die Wysbegeerte van die Wetsidee teenwoordig is. Natuurlik is hier nie sprake van 'n doelbewuste aansluiting by die humanisme en idealisme nie. Die Wysbegeerte van die Wetsidee wil immers 'n konsekwent Christelike filosofie wees. Humanisme en idealisme lê eerder (onbewus) verskuil in sekere aksente van die Wysbegeerte van die Wetsidee. Stoker was in sy opmerking nie met haarklowery besig nie. Inteendeel, uiteensettings van moderne aanhangers van die Wysbegeerte van die Wetsidee toon dat Stoker reeds in die dertigerjare met sy kritiek reg was.

\subsection{Idealistiese trekke}

Dit is opmerklik dat Stoker reeds in sy eerste reeks artikels oor die Wysbegeerte van die Wetsidee in Die Wagtoring die kritiek van idealisme daarteen uitspreek. Dit doen hy nadat hy waarderend die groot betekenis van hierdie Calvinistiese filosofie - ook vir die teologie - aangedui het (1932:(1)), die voorarbeiders van hierdie filosofie, naamlik Bavinck, Geesink en Kuyper bespreek het (1932(2), 1932(3)) en 'n tetiese uiteensetting van die Wysbegeerte van die Wetsidee gegee het (1932(4)). In die vyfde artikel lewer Stoker sy kritiek teen die Wysbegeerte van die Wetsidee. Daarin noem hy dat wetsidee as enigste Archimedespunt te 
eng is. (Grepe van Stoker se betoog is aan die begin van hierdie artikel weergegee.) In verband met die engheid van die wetsidee wys Stoker vervolgens op die gevaar van idealisme. Stoker (1932(5):21) haal Dooyewaard aan wat sê "Heel de werkelijkheid van hoog tot laag is zin, die uit de religieuse zinvolheid zijn oorsprong neemt", en vervolg dan: "Hierdie stelling is die logiese konsekwensie van die wetsidee as die ell die enige argemedes-punt".

$\mathrm{Na}$ aanleiding van die stelling vra hy of Dooyeweerd nie hier in 'n "-isme" - 'n "zin"-isme - verval nie. Stoker wil egter 'n meer bekende -isme gebruik en teken die posisie van Dooyeweerd as "objektief-idealisties en nie realisties" nie; of, as realisme in 'n breër sin gebruik word, as "ideëel-realisties" (Stoker, 1932(6):22, 24). In die mate waarin die hele werklikheid formeel net vanuit die wetsidee gesiell word, is hierdie beskouing wetsfonnalisties of 'n nomologisisme. Stoker (1932(5):22) verduidelik:

Die 'isme' van die 'objektiewe idealisme' is gegee in die bepaling: Heel de werkelijkheid is zin. As D gesê het: Die hele werkelikheid in sy geheel en alle dele het zin, dan was dit geen '-isme' nie, omdat dan opening gelaat word vir die 'meer-as-sin-heid', naamlik die kreatuurlikheid of geskapenheid van die wereld. Gods skepping is tog ongetwyfeld meer as sin, al het hy oorals sin. Gods skepping werk en swoeg, en al het die werking en swoeging sin, die sin van werking en swoeging is nie die werking en swoeging self nie: Daar is nie alleen die 'religieuse sin-volheid' van die kosmos nie, maar ook die 'religieuse aktiwiteits-volheid' van die kosmos ...

'n Werkelikheid ... wat net $\sin$ is, vereis Gods soevereine skeppende denke en wetgewing, - maar 'n werkelikheid, wat ook meer as sin, - werke-likheid en aktiwiteit is, vereis Gods soevereine (en ek mag wel sê: dinamiese of daad-werkelikc) skeppende wil, wat alleen die dinamiese (en nie net die sin van die dinamiese) uit niks te voorskyn kan roep.

So pleit Stoker vir die "substansiële eie-bestaan" van die skepping, wat nie in religieuse sinvolheid opgaan nie, al het dit ten volle daaraan deel (1932(5):22). Die substansiële eie-bestaan van die skepping het ook 'n eie werking wat sin het maar geen $\sin$ is en daarom ook geen on-sin kan wees nie. In hierdie verband wys Stoker op die werklikheid van die sonde en die gevolge daarvan, wat "tot 'n hoë mate die korrelasie tussen religieuse sinvolheid en religieuse werkings-volheid vernietig" het (1932(5):22-23). Stoker (1932(5):23) wys ook daarop dat, as alles sin genoem word, die logiese funksie die werklikheid tiranniseer, "want 'n mens ken nie net nie, maar handel ook en in sy handeling is gegewe die "meer-dan-sinheid"'.

In sy Koers-arikels, waarin Stoker 'grepe' uit die Wysbegeerte van die Wetsidee behandel, kom weer idealisme en ook humanisme ter sprake. Die eerste kritiese artikel handel oor Dooyeweerd se eis: Ken jouself (Stoker, 1937c). Hy onder- 
skryf Dooyeweerd se betoog oor selfkennis as voorwaarde vir wysgerige denke maar bemerk daarin ook ' $n$ "gevaar - nie soseer in wat gesê word, as in wat nie gesê word nie" en waarsku dat 'n skewe fondamentsteen die gebou van die Calvinistiese wysbegeerte kan laat skeef staan (Stoker, 1937c:14).

Stoker (1937c: 14) kom met die volgende invalshoek:

Kennis is produk van die kennende funksies en die gekende sake ... As ek in my analise van kennis alleen uitgaan van die kenfunksies, verloor ek die (gekende) saak uit die oog; wil ek dan vanuit die standpunt van die kenfunksies die (gekende) saak terugwin, dan bepaal die kenfunksie die aard of die vorm van die (gekende) saak. Die saak word só in die lig van die kenfunksie verstaan, en 'verfunksionaliseer'; so ontstaan rasionalistiese, logisistiese, idealistiese of psigistiese 'saak-opvattinge' - al na gelang u die kenfunksie as redelik, as logies, as ideëel of as psigies opvat. Die teenoorgestelde fout is ook moontlik. Ek kan die ken-funksie negeer, oor die hoof sien en net let op die (gekende) saak, as ek met my analise begin. Wil ek dan van hieruit die kenfunksie, die 'bewussyn', of die logiese benader, het ek dit verloor, en ontwikkel ek 'n materialistiese, of evolusionistiese, of 'realistiese', of ontologistiese, of biologistiese of kousalistiese kenteorie; hier word die eieaard van die ken-aktiwitiet foutiewelik beskou in die lig van die (gekende) saak. Om die juiste analise van ons kennis te kry, moet 'n mens tegelyk uitgaan van die ken-funksie èn van die (gekende) saak, en nagaan hoe elk 'oorspronklik' hul deel tot (my) kennis bydra.

Omdat Dooyeweerd net 'ken uself' as eerste eis stel en nie hiernaas ook die gelykwaardige eis van die gekende saak stel nie, "loop hy gevaar om in sy hele stelsel die ken-funksionele te bevoorreg, en dus na idealisme in een of ander vorm oor te neig" (Stoker, 1937c:15). Natuurlik is hierdie "idealisme" verwater, "deurdat die denke as onselfgenoegsaam erken word", maar "die tendens is in die stelsel aanwesig" (Stoker, 1937c:15). Stoker sien ook in Dooyeweerd se tipering van die bestaanswyse van die kosmos as sin - "'n term wat met die logiese begrype en verstaan korreleer" - die tendens tot idealisme, waardeur "logiese analises ... aan die kosmiese werklikheid ten grondslag" gelê word (Stoker, 1938b:30).

Teenoor die enkele (subjektiewe) pool van Dooyeweerd stel Stoker "'n tweede ingangspoort" tot die Calvinistiese wysbegeerte: "Al U werke loof $U$, o Here", want die gelowige sien in die lig van die Skrif alle skepsels in hulle onselfgenoegsaamheid. "Hulle onselfgenoegsaamheid sien ek nie, omdat ek onselfgenoegsaam is ... dit sou 'n verkleuring van die werklikheid beteken ..." (Stoker, 1937c:15). 


\subsection{Humanistiese trekke}

Stoker sien in die 'ken uself' van Dooyeweerd vervolgens 'n tendens tot humanisme. Oor die selfkennis as enigste voonwaarde vir die filosofie sê Stoker (1937c:16):

Maar as ek nèt dit moet weet, en die kosmos moet ken in die lig van my menslike onselfgenoegsaamheid, as ek in die sin van my selfheid die sin van die hele kosmos moet verstaan, dan stel ek in my kennis die kosmos van my afhanklik - en dit mag nie. Die kosmos is ook onselfgenoegsaaam, al was daar geen menslike 'hart' wat in sy onselfgenoegsaamheid die onselfgenoegsaamheid van die kosmos bewus geword het nie; die kosmos het sy eie 'sin'.

In 'n volgende artikel stel Stoker (1937d:17) weer die tendens tot humanisme aan die orde en verduidelik:

Hy wat die betekenis van die mens oordryf en oorskat, is humanis. Hy kan a) die betekenis van die mens oorskat in sy verhouding tot God, b) in sy verhouding tot die orige deel van die kosmos. Gewoonlik is die humanis in die sin van a) ook humanis in die $\sin$ van b), - en vice versa. In die geval van die wysbegeerte van die wetsidee het ons die merkwaardige posisie dat dit geensins ' $n$ tendens tot humanisme in die $\sin$ van a) vertoon nie, maar myns insiens wel in die $\sin$ van b) ...

Die verhouding van die mens tot die orige deel van die kosmos is myns insiens gegee in twee stellinge: a) die mens is die kroon, die kulminasiepunt van die kosmos; b) mens, dier, plant en stof staan in hul oorspronklikheid of wesensverskil, in hul kringsoewereiniteit ewe onmiddellik tot God, en is in hierdie onmiddellike betrek-wees op God gelykwaardig.

Daarom wys Stoker Dooyeweerd se opvatting af "dat die orige deel van die kosmos on die mens geskape is en eers in sy relasie tot die mens sy sinvervulling vind" en dat die mens gevolglik ook "konsentrasiepunt" van die kosmos is (Stoker, 1937d:17-18; kyk oor die mens as konsentrasiepunt en as "religieuze worteleenheid" van die kosmos, Dooyeweerd, 1949:31-32)

\section{Wysbegeerte van die Skeppingsidee}

In Stoker se kritiek op die Wysbegeerte van die Wetsidee, waarvan enkele aspekte hierbo belig is, bemerk ' $n$ mens telkens hoe Stoker in sy kritiek sy eie standpunt vanuit die skeppingsidee belig. Hieroor het hy in dieselfde tyd wat die artikelreeks in Die Wagtoring ontstaan het, 'n brosjure uitgegee. 
In ons weergawe van Stoker se filosofie beperk ons ons visie tot dit wat in Die Wagtoring en Koers verskyn het, omdat die hooflyne van sy standpunt duidelik in genoemde artikels uitgestippel word.

Die Calvinis, sê Stoker (1932(1):23) moet sy staanplek, sy sleutel om die kosmos te oorsien "soek in iets wat buite die kosmos is en tog nie God self is nie". Drie beginsels is gegee wat die radikale onderskeid tussen God en kosmos na vore bring en gevolglik vir die filosofie as buite-kosmiese Archimedespunt kan dien: die openbaringsbeginsel, wetsbeginsel en skeppingsbeginsel. Die vraag is net, sê Stoker (1932(1):23),

... watter van hierdie sleutels verdien die voorrang in 'n Kalvinistiese wysbegeerte; - watter is die hoofsleutel. Met hierdie sleutel erken ons Gods almagtige soewereiniteit, en loop ons nie die gevaar nie iets in die kosmos te vervals, maar kan ons waarlik objektief alles, wat in die kosmos is ken, soos dit geken moet word.

In die volgende artikel begin Stoker om die drie 'sleutels', wat die grens tussen Skepper en skepping erken en hierdie grens as uitgangspunt aanvaar, te bespreek. Die eerste wat aan die orde kom, is die openbaringsbeginsel, soos uitgewerk deur Bavinck. Stoker het waardering vir Bavinck se werk. "Openbaring en kennisneming is korrelatief" sê Stoker (1932(2):20) en daarom is "die openbaringsbeginsel vir die kalvinis 'n vrugbare kenteoretiese argimedespunt" (1932(2):21). As alomvattende kosmiese en wysgerige beginsel skiet dit egter te kort. Stoker (1932(20:20) formuleer sy kritiek só:

Die skepping Gods is meer as net openbaring, dit is iets wat geskape is en 'n eiesoortige selfstandige waarde het, afgesien van sy moontlikheid as openbaringsinhoud. Met ander woorde die openbaringsbeginsel as 'n omvattende wêreldbeginse ${ }^{2}$ is te eng. Die tweede moeilikheid lê daarin dat openbaring ... heenwys op iemand wat die openbaring gryp ... Openbaring wys dus heen op ' $n$ verstaan van die geopenbaarde, op ' $n$ ken - en geloofsaktiwiteit. Die hele wêreld as 'n ken- en geloofs-relasie te beskou beteken die wêreld self te verloor. Die bestaan van die wêreld is seker nie net ' $n$ gekenworde nie. Die ongekende wêreld kan ook bestaan.

In die res van die artikel (kyk Stoker, 1932(2):21-26) en in die volgende twee artikels (1932(3), 1932(4)) word die tweede 'sleutel', naannlik die wetsidee breedvoering bespreek - dit is trouens die deurlopende tema van hierdie artikelreeks in Die Wagtoring.

2 Stoker se spelling is bchou - ook die variasies (bv. wereld en wêreld) - 'n mooi becld van dic vlocibaarheid van Afrikaans, wat hiér nog in sy 'vormingsjarc' was. 
Enkele aspekte van Stoker se kritiek op die Wysbegeerte van die Wetsidee is in hierdie artikel aan die orde gestel. Die aksent het op sy kritiek (óók van Bavinck se openbaringsidee) gelê en nie op sy waardering nie. In die kritiek skeıner Stoker se 'realisme' immers deur in sy telkense pleidooi vir 'n Wysbegeerte van die Skeppingsidee. Die skepping is nie net openbaring nie, is nie net wetsonderworpe nie maar bestaan ook met 'n eie waarde as skeppingsdaad van God; daarom staan elke skepsel unmittelhar zu Gott. Op grond hiervan wys Stoker die standpunt van Vollenhoven en Dooyeweerd af dat die mens die konsentrasiepunt van die skepping is.

In die lig van Stoker se kritiek op Bavinck én op die Wysbegeerte van die Wetsidee sou 'n mens die indruk kon kry dat Stoker sy eie 'sleutel' (die skeppingsidee) as die enigste korrekte beskou. Dit is egter nie die geval nie. In 'n seldsaam beknopte paragraaf stel Stoker (1933(6):15) sy inklusiewe standpunt aan die orde:

Persoonlik kan ek die wysbegeerte van die wetsidee aanvaar, nes ek $\mathrm{H}$. Bavinck se openbaringswysbegeerte ... ook aanvaar. Maar waar Bavinck te eng is in die sin dat sy beginsel van openbaring in hoofsaak net vir die kennis-probleem geld en nie vir die hele kosmos nie, daar is die wysbegeerte van die wetsidee ook weer te eng daarin, dat dit net geld vir die kosmos (en die kennisprobleem) vanuit sy formele wets-, resp. sins-aspek. Ons het beide wysbegeertes ... nodig, maar moet opklim tot 'n nog meer bevredigende wysbegeerte, wat sowel die van Bavinck as die van Vollenhoven en Dooyeweerd omvat en bowendien nog gee, wat hierdie wysbegeertes op grond van hulle respektiewelike argimedespunte nie kan gee nie - 'n wysbegeerte wat die openbaringsbeginsel en die wets-idee as grondleggend erken, maar hulle beide nog dieper fundeer op daardie argimedes-punt, wat die mees omvattende is, die skeppingsidee, in Genesis 1 vers 1. Die skepping immers omvat openbaring en wet, maar is meteen meer as openbaring en wet (afsonderlik en saam geneem).

\section{Slot}

Hierdie artikel was niks meer as 'n kursoriese, tetiese uiteensetting van aspekte van Stoker se kritiek op (hoofsaaklik) die Wysbegeerte van die Wetsidee nie. Dit is onderneem met die hoop dat dit vrug kan dra. Eerstens vrug dáárin dat die aandagtige leser geprikkel sal word deur Stoker se beskouings (veral van die eenheid en wisselwerking van die wetenskappe) om interfakultêre samewerking aan die Potchefstroomse Universiteit nog verder en vrugbaarder uit te bou. Tweedens vrug dáárin dat filosowe weer gaan besin of hulle Archimedespunt nie te eksklusief-eensydig is nie, sodat sommige probleme nie opgelos kan word nie of kunsmatig verklaar moet word (kyk Stoker, 1932(5):20). Ten slotte vrug dáárin dat teoloë weer kennis neem van Stoker se kritiek en in die lig van moderne teologiese uiteensettings in die kader van die Wysbegeerte van die Wetsidee (bv. dié 
van Spykman, 1991, 1992 en Ouweneel, 1993) gaan besin in watter mate sy kritiek nog relevant is.

\section{Bibliografie}

DOOYEWEERD, H. 1935. De Wijsbegeerte der Wetsidee, boek 1 en 2. Amsterdam : Paris.

DOOYEWEERD, H. 1949. Reformatie en scholastiek in de wijsbegeerte, Boek 1. Franeker Wever.

OUWENEEL, W.J. 1993. A Critical Analysis of the External and Internal Prolegomena of Systematic Theology. Bloemfontein : UOVS. (D.Th.-proefskrif.)

SPYKMAN, G.J. 1991. Spectacies. Repr. Potchefstroom : PU for CHE

SPYKMAN, G.J. 1992. Reformational Theology. A New Paradigm for Doing Dogmatics. Grand Rapids : Eerdmans.

STOKER, H.G. 1932-1933. Die nuwere wysbegeerte aan die Vrije Universiteit. Die Wagtoring, 4(18)-5(24). Die verskillende aflewerings van die artikel oor twee jaargange word deur deurlopende nommers tussen hakies soos volg aangedui:

1932(1). Die Wagtoring, 4(18):20-26.

1932(2). Die Wagtoring, 4(19):18-26.

1932(3). Die Wagtoring, 4(20):19-27.

1932(4). Die Wagtoring, 4(21):18-32.

1932(5). Die Wagtoring, 4(22):11-28.

1932(6). Die Wagtoring, 5(23):14-16.

1933(7). Die Wagloring, 5(24):29-39.

STOKER, H.G. 1937a. God (Theos) en wêreld (Kosmos). Koers, 4(4):4-13. (Herdruk in Stoker, 1970:9-17.)

STOKER, H. . 1937b. Die Wysbegeerte van die Wetsidee. Koers, 4(5):2-7.

STOKER, H.G. 1937c. Grepe uit die Wysbegeerte van die Wetsidee. "Ken Uself", Koers, $5(1): 11-17$.

STOKER, H.G. 1937d. Grepe uit die Wysbegeerte van die Wetsidee. Sy naam. Koers, $5(2): 17-24$

STOKER, H.G. 1938a. Grepe uit die Wysbegeerte van die Wetsidee Nog eens die Wetskringleer. Koers, 6(1):8-14.

STOKER, H.G. 1938b. Die Wysbegeerte van die Wetsidee: Die individualiteitstrukture. Koers, 6(2):24-30.

STOKER, H.G. 1940a. Grepe uit 'n Calvinistiese wysbegeerte. Koers, 7(6):1-11.

STOKER, H.G. 1940b. Grepe uit 'n Calvinistiese wysbegeerte. Die verhouding tussen Teologie en Wysbegeerte. Koers, 7(6):1-11.

STOKER, H.G. 1940c. Grepe uit 'n Calvinistiese wysbegeerte. Terreinafbakening tussen Teologie, Wysbegeerte en Vakwetenskap. Koers, 8(3):101-111.

STOKER, H.G. 1941. Iets oor 'n Calvinistiese wysbegeerte. (In Koers in die Krisis. Artikels versamel deur die FCSV. Stellenbosch : Pro-ecclesia. p. 256-280.)

STOKER H.G. 1970. Oorsprong en rigting, band II. Kaapstad: Tafelberg.

VOLLENHOVEN, D.H.Th. 1933. Het Caivinisme en de reformatie van de wijsbegeerte. Amsterdam : Paris. 